\title{
Acclimation and adaptation to irradiance in symbiotic dinoflagellates. I. Responses of the photosynthetic unit to changes in photon flux density
}

\author{
Roberto Iglesias-Prieto*, Robert K. Trench \\ Department of Biological Sciences, University of California at Santa Barbara, Santa Barbara, California 93106, USA
}

\begin{abstract}
The photosynthetic responses to variations in photon flux density were determined for Symbiodinium microadriaticum, the symbiont of the Caribbean jellyfish Cassiopeia xamachana, $S$. kawagutii, the symbiont of the Indo-Pacific stony coral Montipora verrucosa, and $S$. pilosum, the symbiont of the Caribbean zoanthid Zoanthus sociatus. Photosynthetic responses were characterized in terms of cellular pigment content, photosynthesis versus irradiance $(P-I)$ relationships, and number and size of the photosynthetic unit (PSU). Analyses of the responses under 2 light regimes of 40 and $250 \mu \mathrm{mol}$ quanta $\mathrm{m}^{-2} \mathrm{~s}^{-1}$ indicate that: (1) the 3 different species cultured under identical conditions possess different photosynthetic characteristics; (2) the 3 species acclimate to low photon flux density by simultaneously increasing the number and size of their PSU; (3) PSU characteristics were not correlated with the parameters of their respective P-Icurves; $(4)$ the 3 species analyzed have different photoacclimatory capabilities which can be correlated with their respective ecological distribution as endosymbionts. As different species demonstrate characteristic responses, photo-acclimatory adjustment in symbiotic dinoflagellates may be under genetic constraints, and thus may represent photo-adaptation (sensu $\mathrm{O}$. Björkman). As a whole, the results suggest that symbiont photo-adaptation may constitute an important axis of niche diversification for the intact associations.
\end{abstract}

KEY WORDS: Photo-acclimation - Photosynthesis - Symbiotic dinoflagellates - Photosynthetic unit Niche diversification

\section{INTRODUCTION}

Symbiotic dinoflagellates form a heterogeneous assemblage which includes members of at least 7 genera in 4 orders (Banaszak et al. 1993). These algae establish specific mutualistic associations with invertebrate hosts ranging from protozoans to mollusks (Taylor 1974, Trench 1987, 1992, 1993). Symbiotic dinoflagellates are commonly referred to in the literature by the trivial term 'zooxanthellae', although this term lacks any taxonomic significance as it has been used to describe any brown symbiont, including diatoms

- Present address: Departamento de Ecológia, Centro de Investigación Científica y de Educacion Superior de Ensenada, Apdo Postal 2732, Ensenada, Baja California, Mexico
(Trench 1992, 1993). There is a large body of evidence demonstrating that symbiotic dinoflagellates are more species diverse than previously recognized. Although it is very difficult to apply the Biological Species Concept to asexual microalgae (Trench \& Blank 1987), dinoflagellate symbionts isolated from different host species and maintained in culture under constant growth conditions consistently show significant morphological, biochemical, physiological, behavioral and genetic differences (Rowan \& Powers 1992, Trench 1992, 1993, Banaszak et al. 1993, McNally et al. 1994).

Symbiotic associations between dinoflagellates and invertebrates are among the most important primary producers in oligotrophic tropical oceans. In coral reefs, symbiotic invertebrates are responsible not only for the high gross production characteristic of these 
ecosystems (Muscatine 1980), but for the construction and maintenance of the reef framework (Goreau \& Goreau 1959, Stanley 1981). Carbon fixation and photosynthate translocation by the algal component of these symbioses represent in some instances more than $100 \%$ of the basal metabolic requirements of the intact association (Muscatine 1980, Muscatine et al. 1981, Falkowski et al. 1984, Porter et al. 1984). Photosynthetic activity by the symbiotic algae has been implicated in the high $\mathrm{CaCO}_{3}$ deposition rates of hermatypic corals (Goreau \& Goreau 1959, Goreau 1977. Chalker 1981).

The vertical distribution of symbiotic invertebrates includes the entire euphotic zone. Reef corals live in a strong depth-mediated photon flux and spectral gradient that spans over 2 orders of magnitude (Porter 1980 , Porter et al. 1984, Wyman et al. 1987). In addition, the 3-dimensional complexity of the coral reef produces shaded habitats at all depths (Sheppard 1981, Chang et al. 1983). The amount of light received by endozoic algae is modified by the host tissues, and in some cases it is attenuated by self-shading due to close packing of symbionts (Trench \& Fisher 1983). The vertical distribution patterns of individual symbioses are very predictable; dominance of one species of coral in parts of the depth gradient produces obvious zonation patterns in Caribbean reefs (Goreau 1959, Porter 1972, Kinzie 1973, Jackson 1991). Some symbiotic species have very limited vertical distribution. For example, the chondrophore Vellela vellela is restricted to the air-sea interface, exposed to full sunlight; the zoanthid Zoanthus sociatus inhabits very shallow reef crest environments (Goreau 1959), while the scleractinian Leptoseris fragilis is found exclusively at depths between 95 and $145 \mathrm{~m}$, exposed to very dim light (Schlichter \& Fricke 1991). By contrast, others have wide vertical distributions that include the majority of the euphotic zone. This stratification may be the result of the evolution of adaptations of the symbionts to particular light regimes. In this context, it can be hypothesized that the vertical distribution ranges of individual symbiotic associations are, at least in part, the result of the relative capabilities of their specific symbionts to exploit distinct photic environments.

Given the importance of algal photosynthesis to the nutrition of the intact association, it is not surprising that the responses of symbiotic invertebrates to differences in their photic environments have been extensively studied (Drew 1972, Wethey \& Porter 1976, Dus$\tan 1979,1982$, Titlyanov et al. 1980, Zvalinskii et al. 1980, Falkowski \& Dubinsky 1981, Trench et al. 1981, Porter et al. 1984, Wyman et al. 1987). In the studies cited, photosynthetic responses of the symbionts were deduced from the oxygen production of the intact association. Unfortunately, the variability in host res- piration can mask the photosynthetic responses of the algae (Spencer-Davies 1980, Edmunds \& SpencerDavies 1988). To isolate the photo-acclimatory responses of the algal component from animal interferences, Chang et al. (1983) characterized the photosynthetic responses of 3 species of symbiotic dinoflagellates in culture, using ${ }^{14} \mathrm{C}$ assimilation methods. Although their results clearly show that different species of Symbiodinium respond differently to changes in light regime, their interpretations of the responses of the photosynthetic unit (PSU) were made based on theoretical models in vogue at the time, and not by direct assessment of PSU features. By direct assessment of changes in the PSU, we analyzed the photosynthetic responses of 3 species of Symbiodinium to reduced photon flux density in culture and found that the 3 species photo-acclimate by differentially increasing the number and size of the PSU. Analyses of their photosynthetic responses in terms of daily production indicate that different species of Symbiodinium possess different photo-acclimatory capabilities.

\section{MATERIALS AND METHODS}

Algal cultures. Cultures of Symbiodinium microadriaticum Freudenthal, S. kawagutii and $S$. pilosum Trench \& Blank were grown axenically in 500 ml flasks containing $250 \mathrm{ml}$ of ASP-8A (Blank 1987) at $26^{\circ} \mathrm{C}$, with a $14: 10$ h light: dark photoperiod. Light was provided by cool white fluorescent lamps delivering either $40 \mu \mathrm{mol}$ quanta $\mathrm{m}^{-2} \mathrm{~s}^{-1}$ [low light (LL) hereafter], or $250 \mu \mathrm{mol}$ quanta $\mathrm{m}^{-2} \mathrm{~s}^{-1}$ [high light (HL)] of photosynthetically active radiation (PAR). Photon flux densities were measured inside the culture vessels with a QSL-100 4 $\pi$ sensor (Biospherical Instruments, Inc., San Diego, CA, USA). Cells were acclimated to both light regimes for at least 3 mo prior to the experiments. Cultures were maintained at densities below $1.0 \times 10^{5}$ cells $\mathrm{ml}^{-1}$ to minimize self-shading. All the determinations described below were performed on cells in early exponential growth to ensure homogeneous nutrient status.

Photosynthesis vs irradiance measurements. Photosynthesis vs irradiance determinations ( $P-I$ curves) $(5$ replicates per species per light treatment) were made with a Clark-type $\mathrm{O}_{2}$ electrode (Rank Bros., Bottisham, UK) at $26^{\circ} \mathrm{C}$. Temperature within the jacketed chamber was controlled by an external recirculating water bath (VWR Scientific, Inc., San Francisco, CA, USA). Cells were concentrated by gentle centrifugation (1500 rpm, $5 \mathrm{~min}$ ) in a clinical centrifuge and resuspended in ASP-8A. Three ml of cell suspension containing approximately $1.0 \times 10^{6}$ cells $\mathrm{ml}^{-1}$ was placed in the electrode chamber. $\mathrm{O}_{2}$ tension was reduced to 
$20 \%$ saturation by bubbling with $\mathrm{N}_{2}$ gas (Kurzar \& Alberte 1983), and $\mathrm{NaHCO}_{3}$ was added to a final concentration of $5 \mathrm{mM}$ to prevent $\mathrm{CO}_{2}$ limitation. Cells were exposed sequentially to 16 different irradiances (ranging from 6 to $2490 \mu \mathrm{mol}$ quanta $\mathrm{m}^{-2} \mathrm{~s}^{-1}$ ). Dark respiration was obtained by averaging the $\mathrm{O}_{2}$ consumption values obtained at the beginning and at the end of each experiment. Illumination was provided by a high power fiber optics illuminator (Cuda Products, Jacksonville, FL, USA). The maximum output of the illuminator $\left(2490 \mu \mathrm{mol}\right.$ quanta $\left.\mathrm{m}^{-2} \mathrm{~s}^{-1}\right)$ was attenuated by different combinations of neutral density filters. Experimental irradiances were measured with a QSL-100 $4 \pi$ sensor. The electrode was calibrated with air-saturated medium. Data were captured directly by means of a personal computer equipped with an analog/digital converter (Datacan IV, Sable Systems, Salt Lake City, UT, USA). Maximum rates of net photosynthesis $\left(P_{\max }\right)$ were calculated from the average photosynthetic rates obtained for the 4 higher irradiances $(375,714,1360$, and $2490 \mu \mathrm{mol}$ quanta $\mathrm{m}^{-2} \mathrm{~s}^{-1}$ ). The photosynthetic efficiencies $(\alpha)$ were calculated from the linear regression of the light-limited photosynthetic rates in the 0 to $60 \mu \mathrm{mol}$ quanta $\mathrm{m}^{-2} \mathrm{~s}^{-1}$ range $(9$ points including dark respiration). The light saturation intensity for maximal photosynthesis $\left(I_{k}\right)$ was obtained from the intersection of the regression of the light-limited photosynthesis and $P_{\max }$. $P$ - $I$ parameters were also obtained by nonlinear fitting of the data to the Jassby \& Platt (1976) equation. For simplicity, only the parameters obtained by the linear fitting are presented. At the end of each experiment, cell density was estimated in triplicate with a hemacytometer from a $0.1 \mathrm{ml}$ aliquot; the remainder of the sample was concentrated by centrifugation and stored at $-20^{\circ} \mathrm{C}$ for pigment analysis. Daily production $\left(P_{d}\right)$ was calculated for 14 h of net photosynthesis at the experimental light fields, subtracting $10 \mathrm{~h}$ of dark respiration.

Pigment analyses. Samples of algal cells $(2.9 \mathrm{ml})$ were extracted in acetone:dimethyl sulfoxide (DMSO) (90:10, v:v) (Iglesias-Prieto et al. 1992). Cell pellets were resuspended in $0.9 \mathrm{ml}$ of acetone and centrifuged for $10 \mathrm{~s}$ at high speed in a microcentrifuge; the supernatant was saved. The pellet was resuspended in $0.025 \mathrm{ml}$ of DMSO and mixed vigorously for $30 \mathrm{~s}$ with a Vortex mixer. The acetone supernatant was added to the DMSO-extracted sample. Finally the extract was clarified by centrifugation. This operation was repeated 2 or 3 times until a white pellet was obtained. Chlorophyll a (chl a) and chl $c_{2}$ concentrations were determined spectrophotometrically using the equations of Jeffrey \& Humphrey (1975) on a Hewlett Packard 8452A diode array spectrophotometer. Aliquots $(50 \mathrm{ml})$ from the original cultures were concentrated by centrifugation at $8000 \times g$ for $10 \mathrm{~min}$ and extracted in acetone:DMSO as described above. Pigments were transferred to dimethyl-ether, concentrated under $\mathrm{N}_{2}$ gas and separated by thin-layer chromatography (TLC) as described by Jeffrey (1974). Peridinin and chl a were eluted from the TLC plate and their concentrations determined spectrophotometrically as described by Prézelin (1976). Chl a concentrations in native chl-protein complexes were determined using an extinction coefficient of $60 \mathrm{mM}^{-1} \mathrm{~cm}^{-1}$ (Shiozawa et al. 1974).

Determinations of $\mathbf{P}_{700}$ content. Cells were harvested by centrifugation at $8000 \times g$ for 10 min, resuspended in ice-cold TB buffer $[100 \mathrm{mM}$ tris-borate (TB), $\mathrm{pH}$ 8.0, $2 \mathrm{mM} \mathrm{MgCl}_{2}, 2 \mathrm{mM}$ Na-EDTA, $1 \mathrm{mM}$ phenylmethylsulphonyl fluoride], and broken by 3 passes through a French pressure cell at $8.3 \times 10^{7} \mathrm{~Pa}$ (Iglesias-Prieto et al. 1991, 1993). The lysate was clarified by centrifugation at $500 \times g$ for $10 \mathrm{~min}$ at $4^{\circ} \mathrm{C}$ to remove large debris and unbroken cells. The samples were centrifuged at $225000 \times g$ for $2 \mathrm{~h}$ at $4^{\circ} \mathrm{C}$, and the pellets resuspended in $3 \mathrm{ml}$ of ice-cold TB. Thylakoid membranes were made $1 \%(\mathrm{v}: \mathrm{v})$ with $n$-dodecyl $\beta$-D-maltoside (DDM), and solubilized with a PotterElvehjem homogenizer. The solubilized material was clarified by centrifugation at high speed $(12000 \mathrm{rpm}$, $13300 \times g$ ) in a microcentrifuge for $5 \mathrm{~min}$ at $4^{\circ} \mathrm{C}$, diluted to approximately $16.6 \mathrm{mM} \mathrm{chl}$ a (absorbance $=$ 1.00) with ice-cold $\mathrm{TB}$, and rendered $10 \mathrm{mM}$ and $100 \mathrm{mM}$ with methyl viologen and $\mathrm{Na}$ ascorbate, respectively. $P_{700}$ concentrations were determined spectrophotometrically by light-induced bleaching at $698 \mathrm{~nm}$, using $726 \mathrm{~nm}$ as the isobestic point, and a molar extinction coefficient of $64 \mathrm{mM}^{-1} \mathrm{~cm}^{-1}$ (Shiozawa et al. 1974). $P_{700}$ determinations were made with a Hewlett Packard 8452a diode array spectrophotometer as described by Smith \& Alberte (1991). Actinic illumination was provided by a high power fiber optics illuminator, filtered with a broad-band blue filter delivering $40 \mu \mathrm{mol}$ quanta $\mathrm{m}^{-2} \mathrm{~s}^{-1}$. The actinic beam was triggered manually with a mechanical shutter with a full width at half maximum (FWHM) $<0.1 \mathrm{~s}$. The diode array was protected by a broad-band red filter. Under the solubilization conditions described above, approximately $85 \%$ of the chl a present in the purified thylakoids was recovered from the supernatant from which the $\mathrm{P}_{700}$ determinations were made. Preliminary experiments with repetitive extraction of the pellet showed no detectable $\mathrm{P}_{700}$ activity. Similar results were obtained for the water-soluble peridinin-chl aprotein (sPCP) and chl $a-\operatorname{chl} c_{2}$ - peridinin - protein (acpPC) complexes (Iglesias-Prieto et al. 1993). The solubility efficiencies were evaluated from spectroscopic determinations of chl a content in the DDMinsoluble pellet after $90 \%$ acetone extraction.

Chl a: $\mathrm{P}_{700}$ ratios reported here were corrected for solubilization efficiency as well as for the amount of chl a 
present as sPCP and acpPC in the supernatant. Cellular concentrations of $\mathrm{P}_{700}$ were calculated from the molar ratios of chl $a$ : $\mathrm{P}_{700}$ and the cellular chl a content.

$\mathbf{P}_{680}$ determinations. The concentration of $P_{680}$ was determined by the method of Emerson \& Arnold (1932), as described by Mishkind \& Mauzerall (1980) and Kursar \& Alberte (1983). Rates of $\mathrm{O}_{2}$ evolution were determined under single-turnover saturating light flashes with a Clark-type $\mathrm{O}_{2}$ electrode at $26^{\circ} \mathrm{C}$. Repetitive light flashes were provided by 2 synchronously triggered flash lamps (Strovoslave 1539A, General Radio, MA, USA). Cells were concentrated by gentle centrifugation at $1500 \mathrm{rpm}$ in a clinical centrifuge, and resuspended in ASP-8A, at densities of approximately $1 \times 10^{6}$ cells $\mathrm{ml}^{-1}$. The algal suspension was bubbled with $\mathrm{N}_{2}$ gas to reduce the $\mathrm{O}_{2}$ tension to $20 \%$ saturation and the sample was made $5 \mathrm{mM}$ (final concentration) $\mathrm{NaHCO}_{3}$ to prevent $\mathrm{CO}_{2}$ limitation. Optimal $\mathrm{O}_{2}$ :flash yields (about $20 \% \quad P_{\text {max }}$ ) were obtained with flashes delivered between 10 and $20 \mathrm{~Hz}$. Cells were exposed to flashing light for $5 \mathrm{~min}$ before the measurements were performed. Oxygen flux was recorded for 5 to $10 \mathrm{~min}$. The flash lamps were assumed to produce a single photosystem II (PS II) turnover since they have nominal FWHM between 1.6 and $7.5 \mu$ s (Falkowski et al. 1981), which are 2 orders of magnitude smaller than the reported PS II turnover rates for several algal species (Mishkind \& Mauzerall 1980). $P_{680}$ determinations were performed with saturating flash intensities. Analyses of the $\mathrm{O}_{2}$ yield as a function of the relative flash intensity demonstrated that even at half of the maximum output, flashes were saturating. At the end of each experiment cells were harvested by centrifugation, extracted in acetone:DMSO, and chl concentrations determined

Table 1 Symbiodinium spp. Pigment composition of cells grown under 2 experimental photon flux densities, $250 \mu \mathrm{mol}$ quanta $\mathrm{m}^{-2} \mathrm{~s}^{-1}$ (HL) and $40 \mu \mathrm{mol}$ quanta $\mathrm{m}^{-2} \mathrm{~s}^{-1}$ (LL) Pigment concentrations are expressed as $\mu \mathrm{mol}$ cell ${ }^{15}$; values are means of 5 replicates. Values in parentheses represent 1 SEM. The data were analyzed by 1 -way ANOVA

\begin{tabular}{|cccc|}
\hline & LL & HL & p \\
\hline S. microadriaticum & & & \\
Chl $a$ & $3.70(0.14)$ & $1.92(0.04)$ & $<0.01$ \\
Chl $c_{2}$ & $1.75(0.05)$ & $0.95(0.02)$ & $<0.01$ \\
Peridinin & $5.51(0.18)$ & $2.11(0.05)$ & $<0.01$ \\
S. kawagutii & & & \\
Chl a & $2.92(0.14)$ & $2.20(0.10)$ & $<0.01$ \\
Chl $c_{2}$ & $1.42(0.06)$ & $0.95(0.04)$ & $<0.01$ \\
Peridinin & $4.61(0.22)$ & $2.89(0.14)$ & $<0.01$ \\
S. pilosum & & & \\
Chl a & $8.52(0.23)$ & $4.53(0.21)$ & $<0.01$ \\
Chl $c_{2}$ & $4.16(0.11)$ & $2.03(0.09)$ & $<0.01$ \\
Peridinin & $11.60(0.32)$ & $5.49(0.26)$ & $<0.01$ \\
\hline
\end{tabular}

spectrophotometrically as previously described. Dark respiration was measured at the beginning and at the end of each experiment. $\mathrm{O}_{2}$ yields were calculated by adding the rates of dark respiration to the rates of $\mathrm{O}_{2}$ evolution and dividing by the number of flashes. The Emerson \& Arnold photosynthetic unit number was obtained as the molar ratio of chl a: $\mathrm{O}_{2}$ evolved per flash. Assuming that 4 photons are required to evolve a molecule of $\mathrm{O}_{2}$, the Emerson \& Arnold number was divided by 4 to obtain the molar ratio of chl a: $P_{680}$. The ratio of total pigment: $P_{680}$ was calculated from the chl $a$ :chl $c_{2}$ and $c h l a$ :peridinin molar ratios. Cellular content of $\mathrm{P}_{680}$ was calculated as the product of cellular chl a concentrations and the molar ratio of chl a: $P_{680}$.

\section{RESULTS}

Consistent with previous observations (Chang et al. 1983), the 3 species of Symbiodinium analyzed had significantly higher cellular concentrations of photosynthetic pigments when grown at LL than when grown at HL $(\mathrm{p}<0.01)$ (Table 1). Comparisons of the molar ratios of $\mathrm{chl} a$ :chl $c_{2}$, and chl a:peridinin indicate that in LL cells the cellular content of accessory pigments were disproportionately larger than chl a content relative to $\mathrm{HL}$ cells (Table 2 ). The only deviation from this pattern was observed in the $\operatorname{chl} a: \operatorname{chl} c_{2}$ ratio in $S$. microadriaticum.

The photosynthetic responses of Symbiodinium microadriaticum grown at HL and LL are shown in Fig. 1. $P_{\max }$ normalized to cell number was $24 \%$ higher in LL cells $(p<0.01)$, and LL cells showed an $82 \%$ higher $\alpha$ and a $30 \%$ lower $I_{k}$ than HL cells (Table 3 ). Dark respiration was $56 \%$ higher in LL cells ( $p<0.05)$, but no significant differences were observed in the $P_{\max }: R$ (respiration) ratio. When the results were normalized to chl a, $P_{\max }$ of LL cells was $36 \%(\mathrm{p}<0.01)$ lower than $\mathrm{HL}$

Table 2. Symbiodinium spp. Ratios of photosynthetic pigments in cells grown under LL and HL conditions

\begin{tabular}{|lll|}
\hline & LL & HL \\
\hline S. microadriaticum & & \\
Chl a: chl $c_{2}$ & 2.10 & 2.02 \\
Chl a: peridinin & 0.67 & 0.91 \\
Chl a:total pigment & 0.34 & 0.39 \\
S. kawagutii & & \\
Chl a:chl $c_{2}$ & 2.06 & 2.31 \\
Chl a:peridinin & 0.63 & 0.76 \\
Chl a: total pigment & 0.33 & 0.36 \\
S. pilosum & & \\
Chl a:chl $c_{2}$ & 2.06 & 2.23 \\
Chl a:peridinin & 0.73 & 0.83 \\
Chl a:total pigment & 0.35 & 0.36 \\
\hline
\end{tabular}



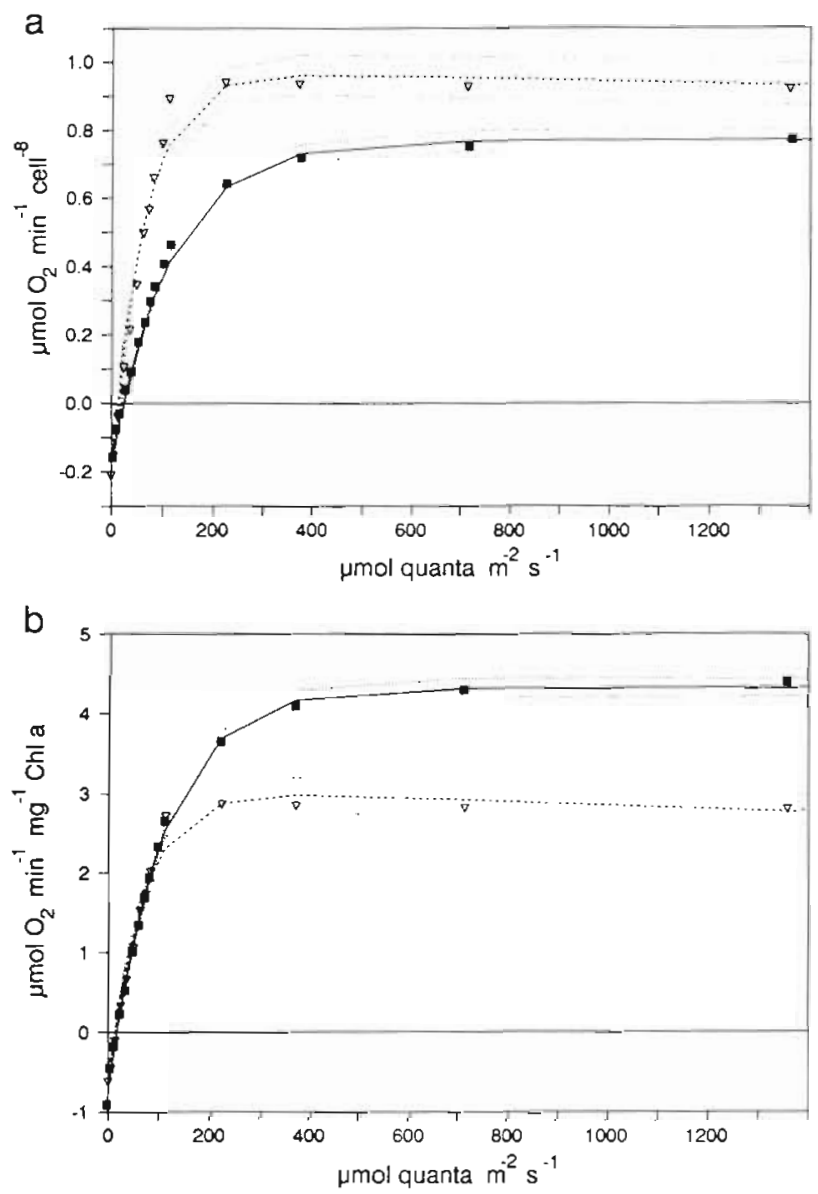

Fig. 1. Symbiodinium microadriaticum. Photosynthesis vs irradiance curves normalized to (a) cell number and (b) chl a content, for cells grown at high $(\longrightarrow)$ and low $(----)$ photon flux densities. For clarity, the values of photosynthesis at the highest irradiance $\left(2490 \mu \mathrm{mol}\right.$ quanta $\left.\mathrm{m}^{-2} \mathrm{~s}^{-1}\right)$ were not included. Each symbol represents the average of 5 individual determinations. For comparison, pooled data were fitted with a non-linear procedure to the Jassby \& Platt (1976) equation. Dotted lines indicate the $95 \%$ limits of confidence of the fits

cells (Table 4 ). Photosynthetic efficiencies $(\alpha)$ of cells grown under the 2 light regimes in terms of chl a were identical (Table 4). Normalization of $P_{\max }$ to cell volume was not performed since cultured symbiotic dinoflagellates are polymorphic; tetrads, and cells in coccoid and motile stages, have different dimensions, and they occur simultaneously in growing cultures (Schoenberg \& Trench 1980, Trench \& Blank 1987). Synchronized cell cultures have never been achieved.

The $P$-I curves normalized to cell number and chl a content from HL and LL cultures of Symbiodinium kawagutii are shown in Fig. 2. Statistical analyses of the $P-I$ parameters normalized to cell number show that $P_{\max }$ values of LL cells were $32 \%$ lower than those of HL cells $(p<0.01)$. Photosynthetic efficiencies of LL cells were $35 \%$ higher $(\mathrm{p}<0.01)$ than those measured
Table 3. Symbiodinium spp. Photosynthesis-irradiance parameters normalized to cell number. $P_{\max }$ and respiration $(R)$ values are expressed as $\mu \mathrm{mol} \mathrm{O}_{2} \mathrm{~min}^{-1} \mathrm{cell}^{-9} I_{k}$ values are expressed as $\mu$ mol quanta $\mathrm{m}^{-2} \mathrm{~s}^{-1}$ Values are means of 5 replicates. Values in parentheses are 1 SEM. The data were analyzed by 1 -way ANOVA. ns: not significant

\begin{tabular}{|cccc|}
\hline & LL & HL & $\mathrm{p}$ \\
\hline S. microadriaticum & & & \\
$P_{\max }$ & $9.268(0.432)$ & $7.499(0.231)$ & $<0.01$ \\
$\alpha\left(\times 10^{-10}\right)$ & $1.038(0.006)$ & $0.570(0.021)$ & $<0.01$ \\
$I_{k}$ & $109.1(7.3)$ & $154.0(10.0)$ & $<0.01$ \\
$R$ & $1.834(0.291)$ & $1.178(0.049)$ & $<0.05$ \\
$P_{\max }: R$ & $6.08(0.86)$ & $6.41(0.40)$ & $\mathrm{ns}$ \\
$S . k_{\text {a }}$ & & & \\
$P_{\max }$ & $5.302(0.116)$ & $7.908(0.304)$ & $<0.01$ \\
$\alpha\left(\times 10^{-10}\right)$ & $0.871(0.022)$ & $0.643(0.022)$ & $<0.01$ \\
$I_{k}$ & $67.4(1.0)$ & $122.7(1.7)$ & $<0.01$ \\
$R$ & $0.438(0.058)$ & $1.135(0.116)$ & $<0.01$ \\
$P_{\max }: R$ & $13.71(1.95)$ & $7.37(3.11)$ & $<0.01$ \\
$S$. Pilosum & & & \\
$P_{\max }$ & $10.910(0.818)$ & $15.580(0.336)$ & $<0.01$ \\
$\alpha\left(\times 10^{-10}\right)$ & $0.787(0.022)$ & $0.643(0.022)$ & $\mathrm{ns}$ \\
$I_{k}$ & $85.5(2.8)$ & $124.9(5.2)$ & $<0.01$ \\
$R$ & $2.029(0.357)$ & $2.070(0.468)$ & $\mathrm{ns}$ \\
$P_{\max }: R$ & $6.28(1.32)$ & $8.99(1.58)$ & $\mathrm{ns}$ \\
\hline
\end{tabular}

for HL cells. The $I_{k}$ of LL cells was $45 \%$ less than HL cells $(p<0.01)$. Dark respiration of LL cells decreased by $61 \%$, and the $P_{\max }: R$ ratio was $86 \%$ higher relative to HL cells $(p<0.01)$ (Table 3$)$. When the $P$-I parameters were normalized to chl $a, P_{\max }$ of LL cells was $48 \%$ lower than HL cells $(p<0.01)$. There was no significant difference in $\alpha$ (Table 4).

The photosynthetic responses of Symbiodinium pilosum grown under LL and HL conditions, normalized to cell number and chl a content, are shown in Fig. 3. The

Table 4. Symbiodinium spp. Photosynthesis-irradiance parameters normalized to chl a. Values are means of 5 replicates. $P_{\max }$ values are expressed as $\mu \mathrm{mol} \mathrm{O}_{2} \mathrm{mg}^{-1} \mathrm{chl} \mathrm{a} \mathrm{min}^{-1} . I_{k}$ values are $\mu \mathrm{mol}$ quanta $\mathrm{m}^{-2} \mathrm{~s}^{-1}$. Values in parentheses are 1 SEM. The data were analyzed by 1-way ANOVA. ns: not significant

\begin{tabular}{|c|c|c|c|}
\hline & LL & $\mathrm{HL}$ & $\mathrm{p}$ \\
\hline \multicolumn{4}{|c|}{ S. microadriaticum } \\
\hline$P_{\max }$ & $2.728(0.099)$ & $4.283(0.130)$ & $<0.01$ \\
\hline$\alpha$ & $0.032\left(2.23 \times 10^{-5}\right)$ & $0.032\left(5.56 \times 10^{-7}\right)$ & ns \\
\hline$I_{k}$ & $106.1(7.3)$ & $154.0(10.0)$ & $<0.01$ \\
\hline \multicolumn{4}{|c|}{ S. kawagutii } \\
\hline$P_{\max }$ & $2.044(0.019)$ & $4.046(0.071)$ & $<0.01$ \\
\hline$\alpha$ & $0.030\left(2.43 \times 10^{-7}\right)$ & $0.033\left(3.94 \times 10^{-6}\right)$ & ns \\
\hline$I_{k}$ & $67.4(1.0)$ & $122.5(1.7)$ & $<0.01$ \\
\hline \multicolumn{4}{|c|}{ S. pilosum } \\
\hline$P_{\max }$ & $1.432(0.044)$ & $3.883(0.112)$ & $<0.01$ \\
\hline$\alpha$ & $0.020\left(3.36 \times 10^{-6}\right)$ & $0.035\left(1.39 \times 10^{-6}\right)$ & $<0.01$ \\
\hline$I_{k}$ & $85.5(2.8)$ & $125.9(5.2)$ & $<0.01$ \\
\hline
\end{tabular}



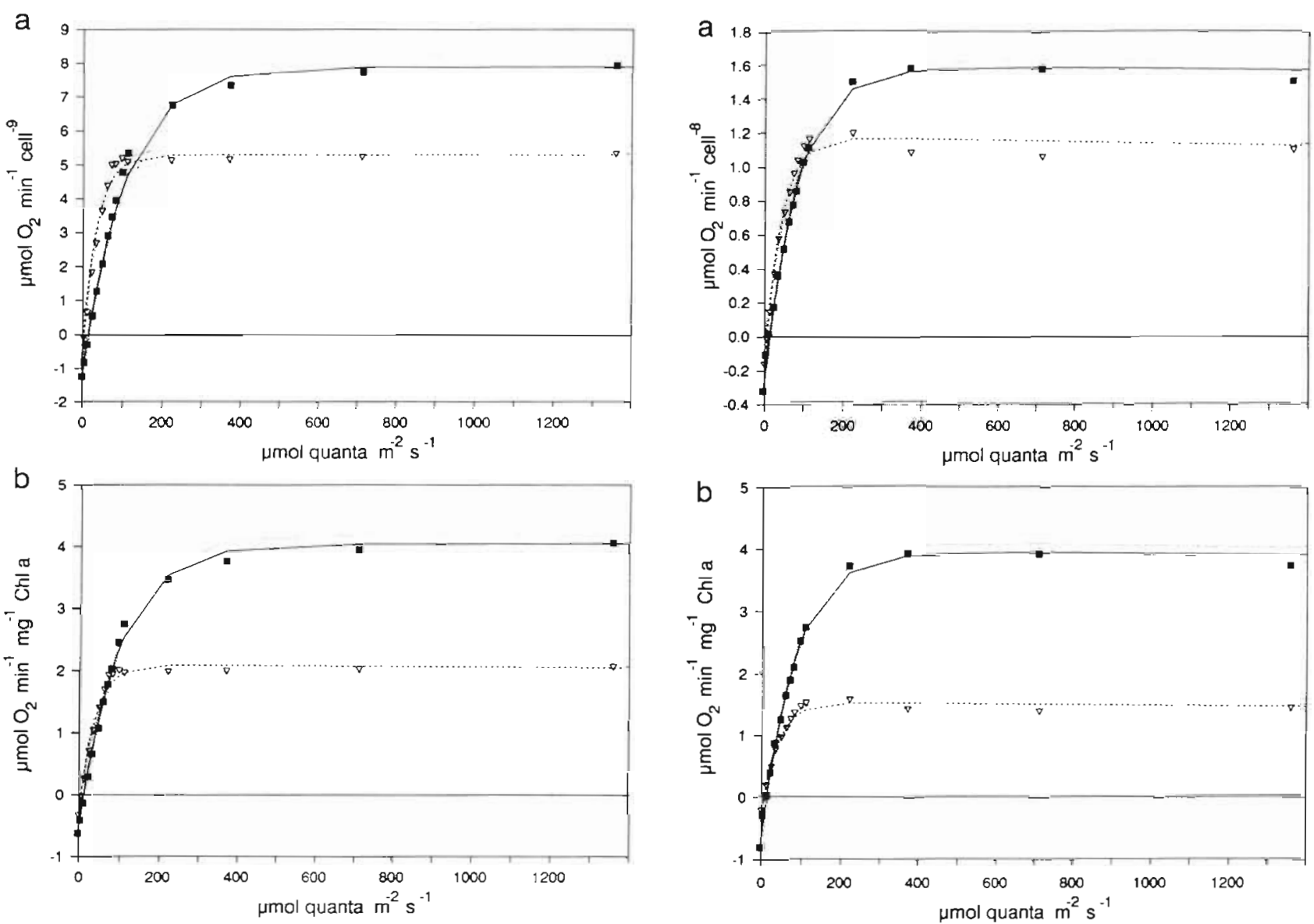

Fig. 2. Symbiodinium kawagutii. Photosynthesis vs irradiance curves normalized to (a) cell number and (b) chl a content, for cells grown at high $(\longrightarrow)$ and low $(\cdots--)$ photon flux densities. For clarity, the values of photosynthesis at the highest irradiance ( $2490 \mu \mathrm{mol}$ quanta $\mathrm{m}^{-2} \mathrm{~s}^{-1}$ ) were not included. Each symbol represents the average of 5 individual determinations. For comparison, pooled data were fitted with a non-linear procedure to the Jassby \& Platt (1976) equation. Dotted lines indicate the $95 \%$ limits of confidence of the fits

$P_{\max }$ of LL cells, normalized to cell number, is $30 \%$ less than HL cells $(\mathrm{p}<0.01)$. The $\alpha$ values were identical. $I_{k}$ values for LL cells were $32 \%$ lower than HL cells $(\mathrm{p}<$ 0.01 ). No differences were detected in the dark respiration and $P: R$ ratios (Table 3 ). When the parameters of the $P$ - $I$ curves were normalized to chl $a, P_{\max }$ and $\alpha$ were $63 \%(\mathrm{p}<0.01)$ and $42 \%(\mathrm{p}<0.01)$ lower, respectively, in LL cells (Table 4 ).

Characteristics of the PSU of Symbiodinium microadriaticum cultured at high and low photon flux densities are summarized in Table 5. The size of PS II (PSU$\mathrm{O}_{2}$ ) in terms of chl a (chl a: $\mathrm{P}_{680}$ ) of LL cells was $37 \%$ higher than in HL cells $(\mathrm{p}<0.01)$. When PSU-O $\mathrm{O}_{2}$ was calculated based on total pigments (chl $a+\operatorname{chl} c_{2}+$ peridinin), the value obtained for LL cells was $61 \%$ higher than HL cells $(p<0.01)$. On a cellular basis, $P_{680}$

Fig. 3. Symbiodinium pilosum. Photosynthesis vs irradiance curves normalized to (a) cell number and (b) chl a content, for cells grown at high $(--)$ and low (----) photon flux densities. For clarity, the values of photosynthesis at the highest irradiance $\left(2490 \mu \mathrm{mol}\right.$ quanta $\left.\mathrm{m}^{-2} \mathrm{~s}^{-1}\right)$ were not included. Each symbol represents the average of 5 individual determinations. For comparison, pooled data were fitted with a non-linear procedure to the Jassby \& Platt (1976) equation. Dotted lines indicate the $95 \%$ limits of confidence of the fits

was $35 \%$ higher in LL cells. The size of PS I (PSU-P $\mathrm{P}_{700}$ ) of LL cells was significantly smaller than in HL cells $(11 \%)(\mathrm{p}<0.01)$ when the values were calculated in terms of chl a. However, when PSU-P 700 values were calculated in terms of total pigment, no difference was detected. The most dramatic differences observed in terms of the organization of the PSU in this species were (1) a doubling of the cellular concentration of $P_{700}$ in LL cells, and (2) a higher molar ratio of PS I: PS II in LL cells than in HL cells.

A summary of PSU characteristics obtained for Symbiodinium kawagutii exposed to both light treatments is presented in Table 5. Chl a-based PSU $\mathrm{O}_{2}$ was smaller in LL cells $(12 \%)(p<0.01)$. When PSU- $\mathrm{O}_{2}$ was normalized to total pigment, the results were not significantly different. LL cells had a $50 \%$ higher ( $\mathrm{p}<$ 
Table 5. Symbiodinium spp. Photosynthetic unit characteristics of cells grown at high $\left(250 \mu\right.$ mol quanta $\left.\mathrm{m}^{-2} \mathrm{~s}^{-1}\right)$ and low $(40 \mu \mathrm{mol}$ quanta $\mathrm{m}^{-2} \mathrm{~s}^{-1}$ ) photon flux densities. Values in parentheses are $1 \mathrm{SEM}\left(\mathrm{n}=15\right.$ for $\mathrm{P}_{680}$ determinations and $n=9$ for $\left.P_{700}\right)$. Data were analyzed by 1 -way ANOVA

\begin{tabular}{|c|c|c|c|}
\hline & LL & $\mathrm{HL}$ & $\mathrm{p}$ \\
\hline \multicolumn{4}{|l|}{ S. microadriaticum } \\
\hline $\mathrm{Chl} a: \mathrm{O}_{2}$ (molar) & $2527(85)$ & $1851(105)$ & $<0.01$ \\
\hline Chl a: $P_{680}$ (molar $)$ & $632(21)$ & $463(26)$ & $<0.01$ \\
\hline Total pigment: $\mathrm{P}_{680}$ (molar) & $1934(65)$ & $1200(68)$ & $<0.01$ \\
\hline $\mathrm{P}_{680}$ cell $^{-1}$ (moles cell ${ }^{-18}$ ) & $5.899(0.198)$ & $4.355(0.267)$ & $<0.01$ \\
\hline Chl a: $P_{700}$ (molar) & $677(19)$ & $767(37)$ & $<0.01$ \\
\hline Total pigment: $\mathrm{P}_{700}$ (molar) & $2073(57)$ & $1990(97)$ & ns \\
\hline $\mathrm{P}_{700}$ cell $^{-1}$ (moles cell ${ }^{-18}$ ) & $5.497(0.147)$ & $2.599(0.126)$ & $<0.01$ \\
\hline PS I : PS II & 0.931 & 0.596 & \\
\hline \multicolumn{4}{|l|}{ S. kawagutii } \\
\hline Chl a: $\mathrm{O}_{2}$ (molar) & $1912(60)$ & $2081(61)$ & $<0.01$ \\
\hline Chl $a: \mathrm{P}_{680}$ (molar) & $460(15)$ & $520(15)$ & $<0.01$ \\
\hline Total pigment: $\mathrm{P}_{680}$ (molar) & $1462(46)$ & $1429(42)$ & ns \\
\hline$P_{680}$ cell $^{-1}$ (moles cell ${ }^{-18}$ ) & $6.380(0.196)$ & $4.250(0.133)$ & $<0.01$ \\
\hline Chl a: $\mathrm{P}_{700}$ (molar) & $913(19)$ & $817(37)$ & $<0.01$ \\
\hline Total pigment: $P_{700}$ (molar) & $2793(60)$ & $2243(83)$ & $<0.01$ \\
\hline $\mathrm{P}_{700}$ cell $^{-1}\left(\right.$ moles cell $\left.{ }^{-18}\right)$ & $3.217(0.062)$ & $2.721(0.096)$ & $<0.01$ \\
\hline PS I:PS II & 0.504 & 0.640 & \\
\hline \multicolumn{4}{|l|}{ S. pilosum } \\
\hline Chl $a: \mathrm{O}_{2}$ (molar) & $1750\{62\}$ & $1714(89)$ & ns \\
\hline Chl a: $\mathrm{P}_{680}$ (molar) & $432(15)$ & $428(22)$ & ns \\
\hline Total pigment: $P_{680}$ (molar) & $1247(65)$ & $1140(68)$ & $<0.01$ \\
\hline$P_{680}$ cell $^{-1}$ (moles cell ${ }^{-18}$ ) & $19.850(0.632)$ & $10.080(0.553)$ & $<0.01$ \\
\hline Chl a: $P_{700}$ (molar) & $1025(32)$ & $808(14)$ & $<0.01$ \\
\hline Total pigment: $\mathrm{P}_{700}$ (molar) & $2921(92)$ & $2150(38)$ & $<0.01$ \\
\hline$P_{700}$ cell $^{-1}$ (moles cell ${ }^{-18}$ ) & $8.387(0.251)$ & $5.620(0.100)$ & $<0.01$ \\
\hline PS I:PS II & 0.423 & 0.558 & \\
\hline
\end{tabular}

$0.01)$ cellular concentration of PS II than HL cells. PSU$\mathrm{P}_{700}$ values of LL cells were higher (12 and $25 \%$ for chl $a$ and total pigment, respectively) than those of HL cells $(\mathrm{p}<0.01)$. Correlated with the higher PSU-P $\mathrm{P}_{700}$ values observed in LL cells, the cellular content of $P_{700}$ was $18 \%$ higher than in HL cells $(p<0.01)$. The PS I:PS II molar ratio of LL cells was 0.50 , whereas that obtained for HL cultures was 0.64 .

The PSU characteristics obtained for Symbiodinium pilosum are summarized in Table 5. No differences were detected in $\mathrm{PSU}-\mathrm{O}_{2}$ based on chl a. A small (9\%) but significantly higher PSU-O $\mathrm{O}_{2}$, based on total pigment, was observed in LL celis ( $p<0.01$ ). The cellular content of $\mathrm{P}_{680}$ for LL cells was $97 \%$ higher than for $\mathrm{HL}$ cells $(\mathrm{p}<0.01)$. PSU- $\mathrm{P}_{700}$ based on chl $a$ and total pigment, as well as the cellular $\mathrm{P}_{700}$ content of LL cells, were higher than in HL cells $(27,36$, and $49 \%$ respectively) ( $p<0.01$ ). The PS I:PS II molar ratio of HL cells was higher (0.56) than that of LL cells $(0.42)$.

Comparisons of daily production $\left(P_{\mathrm{d}}\right)$ estimated for their respective light fields indicate that in all 3 species, LL cells are less productive than HL cells (Table 6) $(p<0.01)$. To assess the efficacy of photo-acclimation to low photon flux density, the estimated $P_{\mathrm{d}}$ of LL cells was compared with theoretical values calculated, assuming no acclimation, for $14 \mathrm{~h}$ of photosynthesis at $40 \mu \mathrm{mol}$ quanta $\mathrm{m}^{-2} \mathrm{~s}^{-1}$ using the $P$-I curves obtained for HL cells (HL"). The results indicate that in Symbiodinium microadriaticum, $P_{\mathrm{d}}$ in LL cells was $97 \%$ higher

Table 6. Symbiodinium spp. Comparisons of daily production of cells acclimated to high and low photon flux densities. Values are means of 5 replicates. Values in parentheses represent $1 \mathrm{SEM}$. Production is expressed as $\mu \mathrm{mol} \mathrm{O} \mathrm{O}_{2}$ cell ${ }^{-6} \mathrm{~d}^{-1}$. $\mathrm{HL}^{*}$ values were calculated, assuming that no photoacclimation had occurred, by the integration of cellular photosynthesis and respiration at $40 \mu \mathrm{mol}$ quanta $\mathrm{m}^{-2} \mathrm{~s}^{-1}$ on the $P$-I curves obtained from cells grown at high photon flux density. Probabilities resulted from 1-way ANOVAs between the LL and $\mathrm{HL}$ ' data. When the same test was used to compare HL and LL treatments it resulted in $\mathrm{p}<0.01$ in the 3 species. ns: not significant

\begin{tabular}{|lcccc|}
\hline Species & LL & HL & HL & p \\
\hline S. microadriaticum & 2.386 & 5.592 & 1.209 & $<0.01$ \\
& $(0.200)$ & $(0.189)$ & $(0.091)$ & \\
S. kawagutii & 2.382 & 5.962 & 1.480 & $<0.01$ \\
& $(0.087)$ & $(0.307)$ & $(0.119)$ & \\
S. pilosum & 3.826 & 11.850 & 3.531 & ns \\
& $(0.423)$ & $(0.327)$ & $(0.429)$ & \\
\hline
\end{tabular}


than in HL cells ( $\mathrm{p}<0.01)$. In $S$. kawagutii the values of $P_{d}$ for LL cultures were $61 \%$ higher than HL cells ( $p<$ $0.01)$. In $S$. pilosum no significant difference was detected.

\section{DISCUSSION}

The success of mutualistic associations between invertebrates and dinoflagellates in environments with very different photic regimes may be attributed, at least in part, to the photo-acclimatory capacities of their specific algal symbiont. The evidence presented here indicates that the 3 species of Symbiodinium analyzed effectively modify their photosynthetic machinery in response to changes in photon flux density. Furthermore, the results indicate that when different species of symbiotic dinoflagellates are cultured under identical conditions, their photosynthetic responses are different. Comparative analyses of the $P$ - $I$ parameters indicate significant differences in the photosynthetic performance of the 3 species when cultured under identical conditions (Table 7). Similar responses were reported previously for cultured symbiotic dinoflagellates (Chang et al. 1983), but the present effort represents the first attempt to document such responses by direct measurements of PSU features. Each individual species demonstrated a characteristic pattern of photoacclimation.

Analyses of chromophore ratios and spectroscopic characteristics indicate that concomitant with the increase in total pigment observed in LL cells, there is a relative enrichment of accessory pigments in relation to chl a. Details of the distribution of pigments among chorophyll-protein complexes of the cells employed in this study will be published separately

The ubiquitous increase in cellular concentrations of photosynthetic pigments demonstrated by primary producers exposed to low irradiances can be the re-

Table 7. Comparison of the photosynthetic performance of the 3 species of Symbiodinium cultured under identical conditions. Data were compared with a 1-way ANOVA.

\begin{tabular}{lrc} 
& $F$-test & $\mathrm{p}$ \\
\hline $250 \mu$ mol quanta $\mathrm{m}^{-2} \mathrm{~s}^{-1}$ & & \\
$P_{\max }$ & 148.72 & 0.0001 \\
$\alpha$ & 132.09 & 0.0001 \\
$I_{k}$ & 5.05 & 0.0278 \\
$\quad$ Respiration & 3.55 & 0.0721 \\
$40 \mu$ mol quanta $\mathrm{m}^{-2} \mathrm{~s}^{-1}$ & & \\
$P_{\mathrm{mdx}}$ & 22.83 & 0.0001 \\
$\alpha$ & 29.06 & 0.0001 \\
$I_{k}$ & 16.74 & 0.0003 \\
Respiration & 8.42 & 0.0052 \\
\hline
\end{tabular}

sult of 2 non-exclusive photo-acclimatory mechanisms: an increase in the optical cross section of the PSU (increase in PSU size), and/or increases in the number of PSU (Prézelin 1981, 1987, Larkum \& Barrett 1983, Richardson et al. 1983, Falkowski \& LaRoche 1991). The results presented here indicate that the 3 symbiotic dinoflagellates analyzed adjust their photosynthetic apparatus to low photon flux density by a combination of the 2 mechanisms (Table 5), but the changes were differential, independent and species specific.

There are only a few reports in which dinoflagellate PSU characteristics have been determined. Prézelin \& Alberte (1978) reported chl a-based PSU-P 700 sizes of 600 for the free-living dinoflagellates Glenodinium sp. (= Heterocapsa pygmaea) and Gonyaulax polyedra (total pigment PSU-P 700 were 1702 and 2175, respectively). Perry et al. (1981) reported a PSU-P 700 (total chl) for $G$. polyedra grown at $300 \mu \mathrm{mol}$ quanta $\mathrm{m}^{-2} \mathrm{~s}^{-1}$ of 445. Dubinsky et al. (1986), working with Prorocentrum micans, showed that cells grown at $70 \mu \mathrm{mol}$ quanta $\mathrm{m}^{-2} \mathrm{~s}^{-1}$ possessed a PSU-P $\mathrm{P}_{700}$ of 1107, while cells cultured at $600 \mu \mathrm{mol}$ quanta $\mathrm{m}^{-2} \mathrm{~s}^{-1}$ had a PSU$\mathrm{P}_{700}$ of 695 . To the best of our knowledge there is only 1 previous report of PSU- $\mathrm{P}_{700}$ for symbiotic dinoflagellates (Falkowski \& Dubinsky 1981). Symbionts isolated from the coral Stylophora pistillata from habitats with high photon flux density (50 to $90 \%$ of the surface irradiance) had a chl a: $\mathrm{P}_{700}$ molar ratio of $425 \pm 50$, whereas those collected from shade environments 10.3 to $1.0 \%$ of the surface irradiance) had a chl $a: P_{700}$ ratio of $1650 \pm 175$. $P_{700}$ content of cells collected at both light environments was the same (approximately $5.8 \times$ $10^{-18} \mathrm{~mol} \mathrm{cell}^{-1}$ ) (Falkowski \& Dubinsky 1981). The PSU-P 700 values reported in the present communication are very similar to those reported previously for several dinoflagellates and diatoms (Falkowski \& Dubinsky 1981, Falkowski et al. 1981, Dubinsky et al. 1986, Owens \& Wold 1986), the only exception being the results reported by Perry et al. (1981), which are consistently smaller.

There are 2 important factors that can potentially interfere with $\mathrm{P}_{700}$ determinations in dinoflagellates:

(1) A considerable fraction of chl $a$ is associated with chl-protein complexes which cannot be sedimented by low speed centrifugation [even after centrifugation for $2 \mathrm{~h}$ at $225000 \times g$, a large portion of the light-harvesting complexes (Iglesias-Prieto et al. 1991, 1993) remains in the supernatant]. This unsedimented chl a must be taken into account during calculations of chl a: $\mathrm{P}_{700}$. Experiments in which thylakoids were centrifuged at $20000 \times g$ for $2 \mathrm{~h}$ prior to solubilization produced a chl a: $P_{700}$ ratio of $470 \pm 49(n=5)$, whereas the ratio obtained for preparations processed as described in the 'Materials and methods' was $913 \pm 20(n=9)$. 
(2) The surfactant Triton X-100, which is commonly employed for $\mathrm{P}_{700}$ determinations, appears to have a deleterious effect on PS I in dinoflagellates (IglesiasPrieto et al. 1993). Determinations of chl a: $P_{700}$ molar ratios using different concentrations of Triton $X-100$ as a surfactant (0.01 to $1.0 \%, \mathrm{v}: \mathrm{v}$ ) failed to produce ratios smaller than 1756 .

Analyses of dinoflagellate PSU in terms of $\mathrm{P}_{680}$ are even more scarce in the literature than those for $P_{700}$. Zvalinskii et al. (1980) determined that for freshly isolated symbionts from Pocillopora verrucosa, the chl abased PSU-P $\mathrm{P}_{680}$ values ranged from 325 at $20 \mathrm{~m}$ to 467 at $45 \mathrm{~m}$. The $\mathrm{P}_{680}$ content was identical in both instances $\left(4.48 \times 10^{-18} \mathrm{~mol} \mathrm{cell}{ }^{-1}\right)$. Similar results were obtained by Dubinsky et al. (1986) from Prorocentrum micans cultured at 70 and $600 \mu \mathrm{mol}$ quanta $\mathrm{m}^{-2} \mathrm{~s}^{-1}$ (chl a: $\mathrm{P}_{680}$ ratios of 725 and 525, respectively). Chl abased PSU- $\mathrm{O}_{2}$ obtained for the 3 symbiotic dinoflagellates species examined here are similar to those reported for diatoms and free-living and symbiotic dinoflagellates (Zvalinskii et al. 1980, Falkowski et al. 1981, Gallagher et al. 1984, Dubinsky et al. 1986).

Zvalinskii et al. (1980) and Falkowski \& Dubinsky (1981) concluded that symbiotic dinoflagellates acclimate to low irradiances by increasing PSU size. In contrast, our results indicate that the 3 species of symbiotic dinoflagellates analyzed photo-acclimate by simultaneously enlarging the antenna and the number of PSU. The observed differences may be the result of ambiguities associated with the definition of PSU in terms of only 1 photosystem (Falkowski \& LaRoche 1991). In both previous PSU analyses, conclusions were made by measuring PSU in terms of either PS I or PS II, but not both (Zvalinskii et al. 1980, Falkowski \& Dubinsky 1981). The notion that PS I:PS II stoichiometries are variable, and that the variations are dependent on irradiance, has been firmly established for most primary producers (Falkowski et al. 1981, Myers \& Graham 1983, Barlow \& Alberte 1985, Chow et al. 1988, 1990, Guenther et al. 1988).

A possible explanation for the observed differences in the photo-acclimatory mechanisms used by freshly isolated and cultured algae may be related to the nutrient status of the algae. Comparisons of the photosynthetic responses of Symbiodinium pulchrorum (the symbiont of the sea anemone Aiptasia pulchella) in culture and in hospite show significant differences (Chang et al. 1983, Muller-Parker 1984). Cultured cells (in log-phase growth) are nitrogen sufficient, whereas algal cells in hospite may be deficient in nitrogen (Cook et al. 1988, Muscatine et al. 1989; cf. Trench 1993). It is possible that under nutrient-limiting conditions, increasing PSU size could be less demanding in terms of nitrogen than synthesizing a complete PSU. Alternatively, it is also possible that species of sym- bionts isolated from different host species possess different mechanisms of photo-acclimation (Chang et al. 1983). Symbiotic dinoflagellates form a heterogeneous assemblage of at least 7 different genera in 4 orders (Banaszak et al. 1993). There are numerous reports documenting biochemical, physiological, behavioral and genetic differences among members of the genus Symbiodinium (Trench 1987, Trench \& Blank 1987, Rowan \& Powers 1992, McNally et al. 1994). Differences in photosynthetic responses of isolated symbiotic dinoflagellates cultured at identical light regimes have been documented, and presumably reflect different photo-acclimatory mechanisms (Chang et al, 1983). These authors deduced the mechanisms of photo-acclimation from conceptual models and not from direct assessment of PSU (see below). Variations in photoacclimatory mechanisms, comparable with those observed among different species, have been documented for different clones of the diatom Skeletonema costatum (Gallagher et al. 1984, Gallagher \& Alberte 1985). Analyses of the photoacclimatory mechanisms employed by symbiotic dinoflagellates are too scarce to make any secure generalizations about their distribution within the genus Symbiodinium.

The evidence presented here indicates that the parameters of the P-I curves cannot be directly correlated with PSU characteristics. Using conceptual models of PSU organization, several authors have proposed that changes in PSU organization can be detected by simultaneous analyses of the $P$ - $I$ curves and the photosynthetic pigment content alone (Prézelin 1981, 1987). In the particular case of dinoflagellates, most of the photo-acclimation studies have been performed using this approach without any direct PSU assessment (Prézelin 1976, Prézelin \& Sweeney 1978, Chang et al. 1983, Prézelin \& Matlick 1983). Our results indicate that interpretations based exclusively on pigment and $P$ - $I$ curve analyses could result in conclusions that clearly contradict the empirical observations. For example, the conceptual models (Prézelin 1981, 1987) predict that cell-specific values of $P_{\max }$ must be proportional to the number of PSU per cell. Analyses of PSU in the present communication indicate that this is not necessarily the case. Increases in PSU number resulted in higher $P_{\max }$ per cell only in Symbiodinium microadriaticum, whereas $P_{\max }$ for LL cells in the other 2 species was significantly lower than in HL cells. These observations indicate that reliable physiological PSU characterizations required the direct measurement of PSU features. Similar discrepancies between the measured PSU features and those predicted by the theoretical model have been reported in several algae and cyanobacteria (Falkowski et al. 1981, Barlow \& Alberte 1985, Gallagher \& Alberte 1985, Dubinsky et al. 1986). Based on the $P_{\max }$ 
values obtained for $S$. kawagutii in this study using $\mathrm{O}_{2}$ evolution, and those obtained for the same species (same clonal population) by Chang et al. (1983) using ${ }^{14} \mathrm{C}$ incorporation, the calculated photosynthetic quotients (PQ) of the LL and HL cells were 2.13 and 1.27 , respectively. The $\mathrm{PQ}$ value for $\mathrm{HL}$ cells conforms to the expected for cells using $\mathrm{NO}_{3}{ }^{-}$as a source of nitrogen; the deviation from the expected $P Q$ in $\mathrm{LL}$ cells requires further investigation.

As a result of their photo-acclimatory capabilities, free-living microalgae can maintain high cell division rates in a variety of light regimes (Prézelin 1981, 1987, Richardson et al. 1983). As symbiotic dinoflagellates in hospite are believed to exhibit very low cell division rates (Muscatine et al. 1989), the function of photo-acclimation in these organisms may be the maintenance of high photosynthate translocation rates under different light regimes. Given the importance of translocation to the overall nutrition of holosymbionts (Muscatine 1980, Porter et al. 1984), the different photo-acclimatory responses demonstrated by the 3 species of symbiotic dinoflagellates analyzed suggest that in the absence of any other variable, intact associations specifically harboring the 3 dinoflagellate species would be differentially effective in exploiting any particular light environment. The observed differences in photo-acclimatory capabilities of the algae may result in an effective niche diversification of the intact associations. Differences in the effectiveness of photo-acclimation to low photon flux density in different dinoflagellate species may represent true adaptive (sensu Björkman 1981) responses to both the predictability and amplitude of the light fields present in their natural environments. Symbiodinium microadriaticum is the symbiont of the Caribbean jellyfish Cassiopeia xamachana. The motile nature of $C$. xamachana allows them to actively 'select' their photic regime (Zahl \& McLaughlin 1959). The range of irradiances encountered by $C$. xamachana in its natural habitat is very large, and unpredictable. C. xamachana can be found at various depths in coral reefs and coastal lagoons, including narrow channels below mangrove canopies. Although this environment possesses low average irradiances, it may be subject to short-duration episodes of high photon flux density (sun-flecks), similar to those observed below the canopies of tropical rain forests (Pearcy et al. 1985). The photosynthetic responses of $S$. microadriaticum grown at low photon flux density, in particular the high cell-specific $P_{\max }$ values, indicate that this organism can effectively utilize short pulses of high photon flux density. Under these conditions a large portion of $P_{\mathrm{d}}$ could be the result of the photosynthesis performed under short periods of saturating light.
In contrast, Symbiodinium kawagutii and $S$. pilosum are the symbionts of colonial sessile organisms (the scleractinian Montipora verrucosa from the IndoPacific, and the Caribbean zoanthid Zoanthus sociatus, respectively). Given their sessile nature, these 2 species occupy photic environments that can be characterized by high predictability. The growth pattern of these organisms is indeterminate (Potts 1984, Jackson \& Coates 1986, Jackson 1991). Individual colonies may be exposed to relatively constant photic regimes for periods ranging from tens to hundreds of years. Our results indicate that both algal species acclimated to low irradiances by increasing the number of reaction centers per cell, but this increase did not result in higher cell-specific $P_{\max }$ values. This observation indicates that their photosynthetic capacities are probably limited by the concentration of carbon fixing enzymes, or electron transfer chains (Falkowski et al. 1981, Prézelin 1981, 1987, Chang et al, 1983). Given the high predictability of their photic environments, it would be 'superfluous' for these 2 species to synthesize more carbon fixing enzymes or electron transfer components than those required at one particular depth.

The low efficiency of photo-acclimation to low light exhibited by Symbiodinium pilosum appears to be consistent with the vertical pattern of distribution of the intact association, since the Zoanthus sociatus morph, from which the cells employed in the present study were isolated, occupy exclusively the shallow parts of the reef (Goreau 1959). Montipora verrucosa demonstrates a wide vertical distribution, although growth rates of this species appear to have a negative correlation with irradiance (Coles \& Jokiel 1978). The evidence presented here indicates that the low light photo-acclimation abilities of $S$. kawagutii are higher than those of $S$. pilosum, but cannot account for the growth patterns observed in the field (Coles \& Jokiel 1978). Maximal surface irradiances in coral reefs can be as high as $2500 \mu \mathrm{mol}$ quanta $\mathrm{m}^{-2} \mathrm{~s}^{-1}$. Due to the concentration of light by waves (glitter), flashes of high photon flux densities (>4000 $\mu \mathrm{mol}$ quanta $\mathrm{m}^{-2} \mathrm{~s}^{-1}$ ) have been recorded in shallow parts of the reef (Jokiel 1988). In this context the 'high light' $(250 \mu \mathrm{mol}$ quanta $\mathrm{m}^{-2} \mathrm{~s}^{-1}$ ) experimental light field employed in the present study represents approximately only $10 \%$ of the maximal intensities that organisms would normally encounter in their natural environment.

Assuming that coral symbionts were members of a single species, Connell (1978) suggested that niche diversification among species plays only a minor role in maintaining the high diversity observed in coral reefs. Data presented in this communication clearly demonstrate that different species of Symbiodinium respond differently to equivalent variations in light. Given the high degree of specificity exhibited by sym- 
biotic associations involving dinoflagellates and invertebrates (Trench 1987, 1992), and the importance of algal metabolism for both calcification and nutrition of the intact associations (Goreau 1977, Muscatine 1980, Porter et al. 1984), the results presented here suggest that the role of photo-adaptation as an important axis of niche diversification in reef corals should be reassessed.

Acknowledgements. We dedicate this paper to Prof. Leonard Muscatine, acknowledging his seminal contributions to the study of algal-invertebrate symbioses. We thank Patricia E. Thome for the maintenance of the symbiotic dinoflagellate culture collection, and Dr R. S. Alberte for the use of his stroboscopic lights and for his comments on early drafts of this manuscript. A. T. Banaszak provided editorial comments. R.I.-P. acknowledges a predoctoral scholarship from the Universidad Nacional Autónoma de México. This study was supported by a grant from the Office of Naval Research (NOOO14-92-J-1131) to R.K.T.

\section{LITERATURE CITED}

Banaszak, A. T., Iglesias-Prieto, R., Trench, R. K. (1993). Scrippsiella vellelae sp. nov. (Perinidales) and Gloeodinium viscum sp. nov. (Phytodiniales): dinoflagellate symbionts of two hydrozoans (Cnidaria). J. Phycol. 29: $517-528$

Barlow, R. G., Alberte, R. S. (1985). Photosynthetic characteristics of phycoerythrin-containing marine Synechococcus spp. Mar. Biol. 86: 63-74

Björkman, O. (1981). Responses to different quantum flux densities. In: Lange, O. L., Noble, P. S., Osmond, C. B., Ziegler, H. (eds.) Encyclopedia of plant physiology, Vol. 12A New Series. Springer-Verlag, Berlin, p. 57-107

Blank, R. K. (1987). Cell architecture of the dinoflagellate Symbiodinium sp. inhabiting the Hawaiian coral Montipora verrucosa. Mar. Biol. 94: 143-155

Chalker, B. E. (1981). Simulating light-saturation curves for photosynthesis and calcification by reef-building corals. Mar. Biol. 63: 135-141

Chang, S. S., Prézelin, B. B., Trench, R. K. (1983). Mechanisms of photoadaptation in three strains of the symbiotic dinoflagellate Symbiodinium microadriaticum. Mar. Biol. 76: 219-229

Chow, W. S., Anderson, J. M., Hope, A. B. (1988). Variable stoichiometries of photosystem II to photosystem I reaction centres. Photosynthesis Res. 17: 277-281

Chow, W. S., Anderson, J. M., Melis, A. (1990). The photosystem stoichiometry in thylakoids of some Australian shadeadapted plant species. Aust. J. Plant Physiol. 17: 665-674

Coles, S. L., Jokiel, P. L. (1978). Synergistic effects of temperature, salinity and light on the hermatypic coral Montipora verrucosa. Mar. Biol. 49: 187-195

Connell, J. H. (1978). Diversity in tropical rain forests and coral reefs. Science 199: 1302-1310

Cook, C. B., D'Elia, C. F., Muller-Parker, G. (1988). Host feeding and nutrient sufficiency for zooxanthellae in the sea anemone Aiptasia pallida. Mar. Biol. 98: 253-262

Drew, E. A. (1972). The biology and physiology of algal-invertebrate symbioses. I. The density of symbiotic algal cells in a number of hermatypic hard corals and alcyonarians from various depths. J. exp. mar. Biol. Ecol. 9: 71-75

Dubinsky, Z., Falkowski, P. G., Wyman, K. (1986). Light harvesting and utilization by phytoplankton. Plant Cell Physiol. 27: 1335-1349

Dustan, P. (1979). Distribution of zooxanthellae and photosynthetic chloroplast pigments of the reef-building coral Montastrea annularis Ellis and Solander in relation to depth of a West Indian coral reef. Bull. mar. Sci. 29: 79-95

Dustan, P. (1982). Depth-dependent photoadaptation of zooxanthellae of the reef coral Montastrea annularis. Mar Biol. 68: 253-264

Edmunds, P. J., Spencer-Davies, P. (1988). Post-illumination stimulation of respiration rate in the coral Porites porites. Coral Reefs 7: 7-9

Emerson, R., Arnold, W. (1932). A separation of the reactions of photosynthesis by means of intermittent light. J. gen. Physiol. 15: 391-420

Falkowski, P. G., Dubinsky, Z. (1981). Light-shade adaptation of Stylophora pistillata, a hermatypic coral from the Gulf of Eilat. Nature 289: 172-175

Falkowski, P. G., Dubinsky, Z., Muscatine, L., Porter, J. W. (1984). Light and the bioenergetics of a symbiotic coral. BioSci. 34: 705-709

Falkowski, P. G., LaRoche, J. (1991). Acclimation to spectral irradiance in algae. J. Phycol. 27: 8-14

Falkowski, P. G., Owens, T. G., Ley, A. C., Mauzerall, D. C. (1981). Effects of growth irradiance levels on the ratio of reaction centers in two species of marine phytoplankton. Plant Physiol. 66: 592-595

Gallagher, J. C., Alberte, R. S. (1985). Photosynthetic and cellular photoadaptive characteristics of three ecotypes of the marine diatom Skeletonema costatum (Grev.) Cleve. J. exp. mar. Biol. Ecol. 94: 233-250

Gallagher, J. C., Wood, A. M., Alberte, R. S. (1984). Ecotypic differentiation in the marine diatom Skeletonema costatum: influence of light intensity on the photosynthetic apparatus. Mar. Biol. 82: 121-134

Goreau, T. F. (1959). Ecology of Jamaican coral reefs. I. Species composition and zonation. Ecology 40: 69-90

Goreau, T. F., Goreau, N. I. (1959). The physiology of skeleton formation in corals. II. Calcium deposition by hermatypic corals under various conditions in the reef. Biol. Bull. 117: $239-250$

Goreau, T. J. (1977). Coral skeletal chemistry: physiological and environmental regulation of stable isotopes and trace metals in Montastrea annularis. Proc. R. Soc. Lond. B 196: $291-315$

Guenther, J. E., Nemson, J. A., Melis, A. (1988). Photosystem stoichiometry and chlorophyll antenna size in Dunaliella salina (green algae). Biochim. Biophys. Acta 934: 108-117

Iglesias-Prieto, R., Govind, N. S., Trench, R. K. (1991). Apoprotein composition and spectroscopic characterization of the water-soluble peridinin-chlorophyll a-proteins from three symbiotic dinoflagellates. Proc. R. Soc. Lond. B 246: $275-283$

Iglesias-Prieto, R., Govind, N. S., Trench, R. K. (1993). Isolation and characterization of three membrane bound chlorophyll-protein complexes from four dinoflagellate species. Phil. Trans. R. Soc. Lond. B 340: 381-392

Iglesias-Prieto, R., Matta, J. L., Robins, W. A., Trench, R. K. (1992). Photosynthetic response to elevated temperature in the symbiotic dinoflagellate Symbiodinium microadriaticum in culture. Proc. natn. Acad. Sci. U.S.A. 89: 10302-10305

Jackson, J. B. C. (1991). Adaptation and diversity of reef corals. BioSci. 41: 475-482

Jackson, J. B. C., Coates, A. G. (1986). Life cycles and evolution of clonal modular animals. Phil. Trans. R. Soc. Lond. B 313: $7-22$ 
Jassby, A. D., Platt, T. (1976). Mathematical formulation of the relationship between photosynthesis and light for phytoplankton. Limnol. Oceanogr 21:540-547

Jeffrey, S. W. (1974). The use of chromatographic techniques for studying photosynthetic pigments in the ocean. Rep. mar. Biochem. Unit C.S.I.R.O., p. 6-8

Jeffrey, S. W., Humphrey, G. F. (1975). New spectrophotometric equations for determining chlorophylls $a, b, c_{f}$ and $c_{2}$ in higher plants, algae and natural phytoplankton. Biochem. Physiol. Pfl. 167: 191-194

Jokiel, P. L. (1988). Is photoadaptation a critical process in the development, function and maintenance of reef comunities? In: Choat, J. H. et al. (eds.) Proc. Sixth int coral Reef Symp., Townsville 1: 187-192

Kinzie, R. A. (1973). The zonation of the West Indian gorgonians. Bull. mar. Sci. 23: 93-155

Kursar, T A., Alberte, R. S. (1983). Photosynthetic unit organization in a red alga. Relationships between lightharvesting pigments and reaction centers. Plant Physiol. 72: $409-414$

Larkum, A. W., Barrett, J. (1983). Light harvesting processes in algae. Adv. bot. Res. 10: 3-189

McNally, K. L., Govind, N. S., Thomé, P. E., Trench, R. K. (1994). Small subunit ribosomal DNA sequence analyses and a reconstruction of the inferred phylogeny among symbiotic dinoflagellates (Pyrrophyta). J. Phycol. 30: $316-329$

Mishkind, M., Mauzerall, D. C. (1980). Kinetic evidence for a common photosynthetic step in diverse seaweeds. Mar. Biol. 56: 261-265

Muller-Parker, G. (1984). Photosynthesis-irradiance responses and photosynthetic periodicity in the sea anemone Aiptasia pulchella and its zooxanthellae. Mar. Biol. 82: $225-232$

Muscatine, L. (1980). Productivity of zooxanthellae. In: Falkowski, P. G. (ed.) Primary productivity in the sea. Plenum Press, New York, p. 381-402

Muscatine, L., Falkowski, P. G., Dubinsky, Z., Cook, P. A, McCloskey, L. R. (1989). The effect of external nutrient resources on the population dynamics of zooxanthellae in a reef coral. Proc. R. Soc. Lond. B 236: 311-324

Muscatine, L., McCloskey, L. R., Marian, R. E. (1981). Estimating the daily contribution of carbon from zooxanthellae to coral animal respiration. Limnol. Oceanogr. 26: $601-611$

Myers, J., Graham, J. R. (1983). On the ratio of photosynthetic reaction centers $\mathrm{RC} 2 / \mathrm{RC} 1$ in Chlorella. Plant Physiol. 71 : $440-442$

Owens, T. G., Wold, E. R. (1986). Light-harvesting function in the diatom Phaeodactylum tricornutum. I. Isolation and characterization of the pigment-protein complexes. Plant Physiol. 80: $732-738$

Pearcy, R. W., Osteryoung, K., Calkin, H. W. (1985). Photosynthetic responses to dynamic light environments by Hawaiian trees. Plant Physiol. 79: 896-902

Perry, M. J., Talbot, M. C., Alberte, R. S. (1981). Photoadaptation of marine phytoplankton: response of the photosynthetic unit. Mar. Biol. 62: 91-101

Porter, J. W. (1972). Patterns of diversity in Caribbean reef corals. Ecology 53: 744-758

Porter, J. W. (1980). Primary productivity in the sea: coral reefs in situ. In: Fâlkowski, P. G. (ed.) Primary productivity in the sea. Plenum Press, New York, p. 403-410

Porter, J. W., Muscatine, L., Dubinsky, Z., Falkowski, P. G (1984). Primary production and photoadaptation in lightand shade-adapted colonies of the symbiotic coral. Stylophora pistillata. Proc. R. Soc. Lond. B 222: 161-180
Potts, D. C. (1984). Generation times and the quaternary evolution of reef-building corals. Paleobiology 10: 48-58

Prézelin, B. B. (1976). The role of peridinin-chlorophyll aproteins in the photosynthetic light adaption of the marine dinoflagellate, Glenodinium sp. Planta 130: 225-233

Prézelin, B. B. (1981). Light reactions of photosynthesis. Can. Bull. Fish. Aquat. Sci. 210: 1-46

Prézelin, B. B. (1987). The photosynthetic physiology of dinoflagellates. In: Taylor, F. J. R. (ed.) Botanical monographs, Vol. 21, The biology of dinoflagellates. Blackwell Scientific Publications, Oxford, p. 174-223

Prézelin, B. B., Alberte, R. S. (1978). Photosynthetic characteristics and organization of chlorophyll in marine dinoflagellates. Proc. natn. Acad. Sci. U.S.A. 75: 1801-1804

Prézelin, B. B., Matlick H. A. (1983). Nutrient-dependent low-light adaptation in the dinoflagellate Gonyaulax polyedra. Mar. Biol. 74: 141-150

Prézelin, B. B., Sweeney, B. M. (1978). Photoadaptation of photosynthesis in Gonyaulax polyedra. Mar. Biol. 48: $27-35$

Richardson, K., Beardall, J., Raven, J. A. (1983). Adaptation of unicellular algae to irradiance: an analysis of strategies. New Phytol. 93: 157-191

Rowan, R., Powers, D. A. (1992). Ribosomal RNA sequences and the diversity of symbiotic dinoflagellates (zooxanthellae). Proc. natn. Acad. Sci. U.S.A. 89: 3639-3643

Schlichter, D., Fricke, H. W. (1991). Mechanisms of amplification of photosynthetically active radiation in the symbiotic deep-water coral Leptoseris fragilis. Hydrobiologia 216/ 217: 389-394

Schoenberg, D. A., Trench, R. K. (1980). Genetic variation in Symbiodinium (= Gymnodinium) microadriaticum Freudenthal, and specificity in its symbiosis with marine invertebrates. II. Morphological variation in Symbiodinium microadriaticum. Proc. R. Soc. Lond. B 207: 429-444

Sheppard, C. R. C. (1981). Illumination and the coral community beneath tabular Acropora species. Mar. Biol. 64 $53-58$

Shiozawa, J. A., Alberte, R. S., Thornber, J. P. (1974). The P700chlorophyll a-protein. Isolation and some characteristics of the complex in higher plants. Arch. Biochem. Biophys. 165: $338-347$

Smith, J. G., Alberte, R. S. (1991). Characterization of photosystem I-associated polypeptides from the chlorophyll $b$ rich alga Tetraselmis spp. (Pleurastrophyceae) and other chlorophyte algae. J. Phycol. 27: 92-101

Spencer-Davies, P. $(1980)$. Respiration in some Atlantic reef corals in relation to vertical distribution and growth form. Biol. Bull. 158: 187-194

Stanley, G. D. (1981). Early history of scleractinian corals and its geological consequences. Geology 9: 507-511

Taylor, D. L. (1974). Symbiotic marine algae: taxonomy and biological fitness. In: Vernberg, W. D. (ed.) Symbiosis in the sea. University of South Carolina Press, Columbia, $p$. $245-262$

Titlyanov, E. A., Shaposnikova, M. G., Zvalinskii, V. I. (1980). Photosynthesis and adaptation of corals to irradiance. 1 Content and native state of photosynthetic pigments in symbiotic microalgae. Photosynthetica 14: 413-421

Trench, R. K. (1987). Dinoflagellates in non-parasitic symbioses. In: Taylor, F. J. R. (ed.) Botanical monographs, Vol. 21, The biology of dinoflagellates. Blackwell Scientific Publications, Oxford, p. 530-570

Trench, R. K. (1992). Microalgal-invertebrate symbiosis, current trends. Encycl. Microbiol. 3: 129-142

Trench, R. K. (1993). Microalgal-invertebrate symbioses: a review. Endocytobiosis Cell Res. 9: 135-175 
Trench, R. K., Blank, R. J. (1987). Symbiodinium microadriaticum Freudenthal, S. goreauii, sp. nov., S. kawagutii, sp. nov, and S. pilosum: gymnodinioid dinoflage]late symbionts of marine invertebrates. J. Phycol. 23: $469-481$

Trench, R. K., Fisher, C. R. (1983). Carbon dioxide fixation in Symbiodinium microadriaticum: problems with mechanisms and pathways. In: Schenk. H. E. A., Schwemmler, W. (eds.) Endocytobiology. Walter de Gruyter \& Co, Berlin p. $659-675$

Trench, R. K., Wethey, D. S., Porter, J. W. (1981). Observations on the symbiosis with zooxanthellae in the Tridacnidae (Mollusca: Bivalvia). Biol. Bull. 161: 180-198

This article was submitted to the editor
Wethey, D. S., Porter, J W. (1976). Sun and shade differences in productivity of reef corals. Nature 262:281-282

Wyman, K. D., Dubinsky, Z., Porter, J. W., Falkowski, P. G. (1987). Light absorption and utilization among hermatypic corals: a study in Jamaica, West lndies. Mar Bıl. 96: 283-292

Zahl, P. A., McLaughlin, J. J. A. (1959). Studies in marine biology. IV On the role of algal cells in the tissues of marine invertebrates. J. Protozool. 6: 344-352

Zvalinskii, V I., Leletkin, V A., Titlyanov, E. A., Shaposnikova, M. G. (1980). Photosynthesis and adaptations of corals to irradiance. 2. Oxygen exchange. Photosynthetica 14: $422-430$

Manuscript first received: March 16, 1994

Revised version accepted: July 19, 1994 